\title{
Effects of NPK fertilizer rates on the carbohydrate and crude protein contents of three varieties of potato (Solanum tuberosum L.) in Sudan Savanna of Nigeria
}

\author{
H. Yusuf ${ }^{1 *}$, A. Muhammad ${ }^{2}$ and J. M. Ambursa ${ }^{1}$ \\ 1Department of Preliminary Studies, College of Science and Technology, Waziri Umaru Federal Polytechnic, Birnin- \\ Kebbi, Kebbi State, Nigeria. \\ ${ }^{2}$ Department of Crop Science, Kebbi State University of Science and Technology, Aliero, Kebbi State, Nigeria. \\ ${ }^{*}$ Corresponding author. Email: elbatislam@yahoo.co.uk. Tel: +2348036385900.
}

Copyright (C) 2017 Yusuf et al. This article remains permanently open access under the terms of the Creative Commons Attribution License 4.0, which permits unrestricted use, distribution, and reproduction in any medium, provided the original work is properly cited.

Received 10th September, 2017; Accepted 26th September, 2017

\begin{abstract}
Field trials were conducted during the 2015/16 and 2016/17 dry seasons. The aim was to study the effects of NPK fertilizer rates on tuber carbohydrates and crude protein (CP) of three varieties of potato (Solanum tuberosum L.). The research was conducted at Teaching and Research Farm of Kebbi State University of Science and Technology, Aliero, located at Jega in the Sudan savanna zone of Nigeria. Treatments consist of four rates of NPK [20:10:10] fertilizer $\left(0,300,600\right.$ and $\left.900 \mathrm{~kg} \mathrm{NPK} \mathrm{ha}^{-1}\right)$ and three varieties (Bertita, Diamant and Nicola) of potato. Factorial combinations of fertilizer rates and varieties were laid out in a randomized complete block design, replicated three times. The size of each plot was $4.5 \times 3 \mathrm{~m}\left(13.5 \mathrm{~m}^{2}\right)$. Results revealed that CP was affected by the dosage of fertilizer applied. $600 \mathrm{~kg} \mathrm{NPK} \mathrm{ha}^{-1}$ gave the highest CP above which there was no significant increase. Higher tuber carbohydrate content was recorded by Nicola and Bertita than Diamant; while crude protein was highest in Bertita compared to Nicola and Diamant. In this study, Bertita variety was higher in crude protein; and was comparable to Nicola, Bertita was lower ( $p \leq$ 0.05) than Nicola and Diamant in carbohydrates. The use of $600 \mathrm{~kg} \mathrm{NPK} \mathrm{ha}^{-1}$ was optimum for good tuber quality.
\end{abstract}

Key words: Crude protein, NPK fertilizer, Sudan savanna, tuber carbohydrates, variety.

\section{INTRODUCTION}

Irish Potato (Solanum tuberosum L.) is one of the word's prime sources of human nutrition. The protein/ carbohydrate ratio is higher than for most cereals and other tuber and root crops (Okonkwo et al., 1995). In terms of composition, potato tuber contains 70 to $82 \%$ water, 17 to $29 \%$ dry matter, 11 to $23 \%$ carbohydrate, 0.8 to $3 \%$ protein, $0.1 \%$ fat and $1.1 \%$ minerals (Singh, 2004). Production per hectare of important vitamins, such as thiamine, riboflavin, niacin and vitamin $C$ is higher in potato than in other major crops, such as rice, maize and wheat (Rolot, 2001; Okonkwo et al., 1995; Beukema and Vander Zaag, 1990; Harris, 1992). According to Okonkwo et al. (1995), daily consumption of $1 \mathrm{~kg}$ of potato tuber provides all the essential amino acids needed by the body, except cystine and methionin. Apart from more conventional ways of using potato as food stuff, it is now a prominent industrial raw material in developed countries. This has considerably widened the range of possible uses of the crop. In the food sector, potatoes are processed into deep-frogmen chips and mashed potato. By-products such as potato starch, glucose and dextrose are used in the brewing industry, confectionary products and in the distillation of alcohol. In the non-food sector, by- products such as potato starch, starch proper and dextrin are used in processes for the manufacture of cardboard, glues, textiles and paints, and in the laundry business as ironing sprays (Harris, 1992; Rolot, 2001).

High tuber dry matter content is particularly desirable in potatoes for processing. However, according to International Potato Institute, IPI (1993), N and K application reduced tuber dry matter content, with the effect being less by $\mathrm{K}$ than $\mathrm{N}$. However, $\mathrm{P}$ was reported to slightly increase tuber dry matter content. Protein content usually expressed as a percentage of dry matter 
is favorably influenced by increase in $\mathrm{N}$ and $\mathrm{K}$, but reduces by increasing application of $P$ (Singh, 2004). To achieve high tuber quality, it is recommended to apply NPK fertilizer with less $\mathrm{N}$ than $\mathrm{P}$ and $\mathrm{K}$ to potato (Vos, 1999).

Depending on the mineral fertilizer forms, rates and nutrient ratios applied to potatoes; the contents of dry matter, starch, protein and other substances may either increase or decrease. Excessive application of fertilizer reduces starch, dry matter and sugar contents in potato tubers that deteriorate more rapidly in storage (Shock et al., 1999). This results from the fact that nitrogen promotes growth of potato vines, and when lasting drought occurs, the vines that have grown so large are most dramatically affected and the growing season is extended. Tubers harvested under such conditions, may not reach harvest maturity or amass maximum dry matter content, while starch also accumulates less rapidly, since part of it is used for respiration (Eiasu et al., 2007). Dry matter content is affected by various factors, among which the most significant are tuber maturity, growth character, plant nutrient and water uptake (Harris, 1992). Thus, this study was carried out to determine carbohydrates and crude protein contents of some selected potato varieties in response to NPK fertilizer rates.

\section{MATERIALS AND METHODS}

The experiments were conducted during 2015/16 and 2016/17 dry seasons at the Teaching and Research Farm of the Kebbi State University of Science and Technology at Jega (latitude $12^{\circ} 11^{\prime} \mathrm{N}$; longitude $4^{0} 16^{\prime} \mathrm{E}$ ) in the Sudan savanna ecological zone of Nigeria. The climate of the area is semi-arid with average rainfall between 550 to $650 \mathrm{~mm}$ per annum. Relative humidity ranges from 21 to $47 \%$ and 51 to $79 \%$ during the dry and rainy seasons respectively. Temperature ranges between 14 to $30^{\circ} \mathrm{C}$ during dry season and 27 to $41^{\circ} \mathrm{C}$ during the rainy season (Anonymous, 2012). The mean monthly temperatures, relative humidity and solar radiation at the experimental site during the period of the experiments (2014, 2015, 2016 and 2017) are shown in Appendix II.

The treatments consisted of four rates $(0,300,600$ and $\left.900 \mathrm{~kg} \mathrm{ha}^{-1}\right)$ of NPK (20: 10: 10) fertilizer and three potato varieties (Nicola, Bertita and Diamant). The treatments were laid out in a randomized complete block design with three replications. The planting material (seed tubers) for the three varieties was sourced from the Potato Program Unit of the National Root Crop Research Institute (NRCRI) sub-station Vom, Jos, Plateau State. The seed tubers were pre-sprouted for six weeks and dressed with fungicide (Muncozeb powder) a day prior to planting. Planting was done manually with whole or cut tubers of approximately $30 \mathrm{~g}$ weight per hill at intra-row spacing of $30 \mathrm{~cm}$ and a depth of 8 to $10 \mathrm{~cm}$. Plots of $3.0 \times 4.5 \mathrm{~m}(13.5$ $\mathrm{m}^{2}$ ) were marked out, leaving a $1 \mathrm{~m}$ space between main plots. Six ridges spaced $75 \mathrm{~cm}$ apart were constructed in each plot. The net plot area consisted of the two middle rows $(3.0 \times 1.5 \mathrm{~m})\left(4.5 \mathrm{~m}^{2}\right)$.

Water pump machine was used to draw water from a tube well to the field through the water channels. Irrigation was scheduled at 4 to 7 days interval depending on the water need. The whole field was watered 3 days before and after planting. Compound fertilizer (NPK 20: 10: 10) was used at the variable treatment rates of 0 , 300,600 and $900 \mathrm{~kg} \mathrm{NPK} \mathrm{ha}^{-1}$. These rates were applied according to the treatments in two split doses. The first and second doses were applied as basal and at 4 weeks after planting (WAP) respectively. Fertilizer was incorporated about $10 \mathrm{~cm}$ away from each plant stand at $5 \mathrm{~cm}$ depth and covered with soil. Weeds were controlled manually using hoe at 4 and 7 WAP. Karate insecticide (lambdacyhalothrin) was sprayed at $4 \mathrm{ml}$ active ingredient $\mathrm{L}^{-1}$ of water to control insect pests. The crops were harvested on 16th February, 2016 and 11th February, 2017 for the $2015 / 16$ and $2016 / 17$ trials respectively. A light irrigation was given to all plots a day to harvesting to facilitate easy lifting of tubers.

Harvested tubers were sampled from each net plot, sliced to very small pieces and oven-dried at $70^{\circ} \mathrm{C}$ to a constant weight in separate paper bags. The oven-dried tuber samples were grounded, sieved and analyzed for total $\mathrm{N}$ contents in the laboratory using one gram each of the sample by Micro Kjeldhal procedure. The physical and chemical properties of the soil of the experimental site in 2015 and 2016 dry seasons are shown in Appendix I.

The crude protein content of tubers was estimated by multiplying the total nitrogen $(\mathrm{N})$ content of the tuber by 6.25 as described by Yusuf et al. (1999). Tuber carbohydrate content was estimated as Nitrogen Free Extract (NFE) and was calculated as: NFE $=100-$ (crude protein + moisture + crude fiber). Data generated were subjected to analysis of variance (ANOVA) in accordance with Gomez and Gomez (1984). The treatment means were separated using the Duncan's Multiple Range Test (DMRT) (Duncan, 1955) and Statistical Analysis System (SAS).

\section{RESULTS}

\section{Tuber Carbohydrate Content (\%)}

Fertilizer rates did not have any significant effect on percent tuber carbohydrate content throughout the seasons and in the combined data as shown in Table 1. In 2015/16, Nicola had the highest tuber carbohydrate content followed by Diamant, and the lowest was in Bertita. In 2016/17 and the combined data, Nicola and Bertita were at par, with significantly higher percent carbohydrate content than Bertita. Interactions of irrigation intervals, NPK rates and varieties on percent tuber carbohydrate content were not significantly different 
Table 1. Effect of NPK rates on tuber Carbohydrate and Crude protein contents of three potato varieties in 2015 to 2017 dry seasons and the combined data at Jega.

\begin{tabular}{|c|c|c|c|c|c|c|}
\hline \multirow{2}{*}{ Treatments } & \multicolumn{3}{|c|}{ Carbohydrates Content (\%) } & \multicolumn{3}{|c|}{ Crude Protein (\%) } \\
\hline & $2015 / 16$ & $2016 / 17$ & Combined & $2015 / 16$ & $2016 / 17$ & Combined \\
\hline \multicolumn{7}{|l|}{ Variety } \\
\hline Bertita & $74.14 \mathrm{c}$ & $72.28 \mathrm{~b}$ & $72.67 \mathrm{~b}$ & $9.19 a$ & $9.19 a$ & $9.19 a$ \\
\hline Diamant & $82.29 b$ & $83.42 a$ & $83.42 a$ & $8.50 a b$ & $8.44 b$ & $8.50 \mathrm{~b}$ \\
\hline Nicola & $83.57 a$ & $83.64 a$ & $83.62 a$ & $8.13 b$ & $8.25 b$ & $8.13 c$ \\
\hline SE \pm & 0.270 & 0.270 & 0.130 & 0.28 & 0.26 & 0.12 \\
\hline \multicolumn{7}{|c|}{ NPK rates $\left(\mathrm{kg} \mathrm{ha}^{-1}\right)$} \\
\hline 0 & 80.72 & 80.73 & 80.79 & $8.31 \mathrm{~b}$ & 8.56 & $8.23 b$ \\
\hline 300 & 80.43 & 80.72 & 80.59 & $8.31 b$ & 8.49 & $8.24 b$ \\
\hline 600 & 79.96 & 79.54 & 79.99 & 8.96ab & 9.20 & $9.05 a$ \\
\hline 900 & 80.63 & 80.81 & 80.67 & $9.10 \mathrm{a}$ & 9.13 & $9.10 a$ \\
\hline $\mathrm{SE} \pm$ & 0.588 & 0.614 & 0.246 & 0.600 & 0.586 & 0.245 \\
\hline Interactions & NS & NS & NS & NS & NS & NS \\
\hline
\end{tabular}

Means followed by the same letter(s) within a treatment group are not significantly different using DMRT at $5 \%$. Ns= not significant.

in all trials and the combined data.

\section{Tuber Crude Protein Content (\%)}

Effects of fertilizer rate and variety on tuber crude protein (CP) content are presented in Table 1. Application of 600 and $900 \mathrm{~kg} \mathrm{NPKha}{ }^{-1}$ produced similar and significantly higher percent tuber crude protein than the two other rates in 2015/16 and the combined means, except in $2016 / 17$ where 0 and $300 \mathrm{~kg} \mathrm{NPKha}^{-1}$ was at par with 600 $\mathrm{kg} \mathrm{NPKha}^{-1}$. Variety Bertita consistently gave higher tuber crude protein content than Diamant and Nicola in the two trials and the combined data. In the combined data, Diamant in turn gave more crude protein content than Nicola. Interactions of irrigation intervals, NPK rates and variety on tuber crude protein content were not significant in all trials and the combined data.

\section{DISCUSSION}

The CP contents of the tuber were maximized with the application of $600 \mathrm{~kg} \mathrm{NPKha}^{-1}$ above which there was no further significant increase. The high content of the applied fertilizer particularly the 600 and $900 \mathrm{~kg} \mathrm{NPKha}^{-1}$ rates, in addition to the inherent high soil fertility might have resulted in ample uptake and translocation of $\mathrm{N}$, which is a factor in protein synthesis; to the plant system and its subsequent mobilization to other plant parts, including the tubers. According to Adhikari and Sharma (2004), N and K application reduced tuber dry matter content, with the effect being less by $\mathrm{K}$ than $\mathrm{N}$, but $\mathrm{P}$ was reported to slightly increase tuber dry matter content. Protein content usually expressed as a percentage of dry matter was enhanced by increase in $\mathrm{N}$ and $\mathrm{K}$ but reduced by increasing $P$ application (Shukla and Singh, 1976; Ezzat et al., 2011). The significantly high tuber carbohydrate content in varieties Nicola and Bertita over Diamant, and crude protein content in Bertita over Nicola and Diamant further indicated the genetic variation among the three varieties tested in this study (Babaji et al., 2008; Manrique and Barthlomew, 1991).

\section{Conclusion}

In this study, variety Bertita was superior in terms of tuber crude protein; and was similar to Nicola in terms of carbohydrate contents of the tuber. The application of $600 \mathrm{~kg} \mathrm{NPK} \mathrm{ha}^{-1}$ was optimum for crude protein and carbohydrate contents of potato tuber (Bertita, Diamant and Nicola).

\section{CONFLICT OF INTEREST}

The authors declare that they have no conflict of interest.

\section{REFERENCES}

Adhikari, R. C., \& Sharma, M. D. (2004). Use of Chemical fertilizers on Potato in Sandy Loam soil under Humid SubTropical conditions of Chitwa. Nepal Agricultural Research Journal, 5, 23-26.

Anonymous (2012). Annual report of Kebbi State Environmental Protection Agency, 12p. 
Babaji, B. A., Amans, E. B., Chiezey, U. F., Falaki, A. M., \& Hussain, M. A. (2008). Tuber quality and Marketable yield of Irish Potatoes (Solanum TuberosumL.) as influenced by rate of NPK fertilizer and seed form. Research Journal of Science. 15, 75-87.

Beukema, H. P. \& Vander Zaag, D. E. (1990). Marketable yield and plant Population. In: Potato improvement; factors and facts. International Agricultural Centre, Wageningen, the Netherlands, Pp. 35-175.

Duncan D. B. (1955). Multiple Ranges and Multiple F-Test. Biometrics, 11, 1-42.

Eiasu, B. K., Soundy, P., \& Hammes, P. S. (2007). Response of potato (Solanum tuberosum) tuber yield components to gelpolymer soil amendments and irrigation regimes. New Zealand J. Crop Hort. Sci., 35(1), 25-31.

Ezzat, A. S., El-Awady, A. A., \& Ahmed, H. M. A. (2011). Improving Nitrogen Utilization Efficiency by Potato (Solanum tuberosum L.) Effect of Irrigation intervals, Nitrogen rate and Veterra Hydrogen on Growth, Yield, Nutrient uptake and Storability. Nature and Science, 9(7), 34-42.

Gomez, K. A., \& Gomez, A. A. (1984). Statistical Procedure for Agricultural Research (2 ${ }^{\text {nd }}$ Edition). John Willey and Sons, New York. 680p.

Harris, P. (1992). The Potato Crop, the scientific basis for Improvement. Chapman and Hall Ltd. Landon. 909p.

IPI (1993). International Potash Institute Bulletin: Fertilizers for yield and Quality. No. 8. Potato Switzerland. 84p.
Manrique, L. A., \& D. P. Barthlomew (1991). Growth and Yield performance of Potato Grown at three elevations in Hawaii: II. Dry Matter Production and Efficiency of Partitioning. Crop Science, 31, 367-372.

Okonkwo, J. C., Ene, L. S. O., \& Okoli, O. O. (1995). Potato Production in Nigeria. NVRI Press. Vom. Nigeria. 109p.

Rolot, J. L. (2001). Potato. In: Romain, H. R. (ed). Crop Production in Tropical Africa. DGIC Belgium, Pp. 188-204

Shock, C.C., Feibert, E. B. G., \& Saunders, L. D. (2003). Umatilla Russet and Russet Legend potato Yield and Quality Response to Irrigation. Horticultural Science, 38, 1117-1121.

Shukla, D. N., \& Singh, S. J. (1976). Effect of the technique of Potassium application on growth, yield and chemical composition of Potato (Solanum tuberosum L.) Varieties. Potash Review. 16, 71-78.

Singh, S. S. (2004). Soil Fertility and Nutrient Management. Kalyani Publisher. New Delhi, India. 253p

Vos, I. (1999). Split Nitrogen Application in Potato: Effects of accumulation, Nitrogen and Dry matter in the Crop and on the soil nitrogenbudget. Journal of Agricultural Sciences. 199:263-274.

Yusuf, R. L., Siemens, J. C., \& Bullock, D. G. (1999). Growth Analysis of Soyabean under No-tillage and Conventional tillage Systems. Agronomy Journal. 91, 928-933. 
Appendix I. Physical and chemical properties of the soil of the experimental site in 2015-17 dry seasons.

\begin{tabular}{lccc}
\hline Soil properties & $\mathbf{2 0 1 5}$ & $\mathbf{2 0 1 6}$ & $\mathbf{2 0 1 7}$ \\
\hline Physical properties & & & \\
Sand $\left(\mathrm{gkg}^{-1}\right)$ & & & \\
Silt $\left(\mathrm{g} \mathrm{kg}^{-1}\right)$ & 800 & 624 & 687 \\
Clay $\left(\mathrm{g} \mathrm{kg}^{-1}\right)$ & 157 & 254 & 250 \\
Soil Textural Class & 43 & 122 & 103 \\
& Sandy loam & Sandy loam & Sandy loam \\
Chemical properties & & & \\
& & & \\
$\mathrm{pH}(\mathrm{Water})$ & & 5.9 & 6.1 \\
$\mathrm{pH}(\mathrm{CaCl})$ & 5.6 & 5.7 & 5.6 \\
Organic carbon $(\%)$ & 5.5 & 0.8 & 1.0 \\
$\mathrm{~N}\left(\mathrm{gkg}^{-1}\right)$ & 0.4 & 0.37 & 0.52 \\
$\mathrm{P}\left(\mathrm{mgkg}^{-1}\right)$ & 0.32 & 1.21 & 1.29 \\
$\mathrm{~K}(\mathrm{Cmolkg}$ & 1.38 & 0.99 & 0.97 \\
$\mathrm{Na}\left(\mathrm{Cmolkg}^{-1}\right)$ & 0.54 & 0.44 & 0.52 \\
$\mathrm{Ca}\left(\mathrm{Cmol} \mathrm{kg}^{-1}\right)$ & 0.39 & 0.33 & 0.30 \\
$\mathrm{Mg}\left(\mathrm{Cmol} \mathrm{kg}^{-1}\right)$ & 0.45 & 0.70 & 0.85 \\
$\mathrm{CEC}\left(\mathrm{Cmolkg}^{-1}\right)$ & 0.50 & 2.46 & 2.64 \\
\hline
\end{tabular}

Appendix II. Mean monthly temperatures, relative humidity and solar radiation at the experimental site during the period of the experiments (2014 to 2017).

\begin{tabular}{lcccccccccccc}
\hline \multirow{2}{*}{ Months } & \multicolumn{3}{c}{ Temperature $\left({ }^{\circ} \mathbf{C}\right)$} & \multicolumn{4}{c}{ Relative Humidity (\%) } & \multicolumn{3}{c}{ Solar Radiation (kcalcm-2 } \\
\cline { 2 - 13 } & $\mathbf{2 0 1 4}$ & $\mathbf{2 0 1 5}$ & $\mathbf{2 0 1 6}$ & $\mathbf{2 0 1 7}$ & $\mathbf{2 0 1 4}$ & $\mathbf{2 0 1 5}$ & $\mathbf{2 0 1 6}$ & $\mathbf{2 0 1 7}$ & $\mathbf{2 0 1 4}$ & $\mathbf{2 0 1 5}$ & $\mathbf{2 0 1 6}$ & $\mathbf{2 0 1 7}$ \\
\hline January & - & 23.8 & 25.8 & 23.4 & - & 27 & 25 & 24 & - & 14.5 & 15.7 & 14.8 \\
February & - & 26.0 & 27.3 & 25.8 & - & 23 & 22 & 20 & - & 18.3 & 17.4 & 17.6 \\
March & - & 30.8 & 30.7 & 31.7 & - & 22 & 22 & 20 & - & 18.3 & 17.5 & 17.2 \\
April & - & 35.0 & 35.6 & 34.9 & - & 33 & 38 & 30 & - & 18.0 & 17.7 & 17.5 \\
May & - & 33.2 & 33.9 & 34.2 & - & 39 & 35 & 38 & - & 18.7 & 18.6 & 18.3 \\
June & - & 28.2 & 30.4 & 31.4 & - & 52 & 55 & 60 & - & 17.3 & 17.5 & 17.6 \\
July & - & 27.2 & 26.8 & - & - & 70 & 68 & - & - & 15.2 & 15.4 & - \\
August & - & 27.2 & 26.7 & - & - & 79 & 80 & - & - & 14.7 & 14.9 & - \\
September & - & 26.8 & 25.2 & - & - & 78 & 81 & - & - & 17.2 & 17.5 & - \\
October & 29.2 & 26.7 & 28.6 & - & 47 & 62 & 69 & - & 17.8 & 16.4 & 16.8 & - \\
November & 29.4 & 28.4 & 29.6 & - & 29 & 30 & 27 & - & 17.3 & 17.6 & 17.8 & - \\
December & 26.9 & 25.3 & 25.8 & - & 27 & 26 & 25 & - & 16.7 & 16.5 & 16.9 & - \\
\hline
\end{tabular}

